\title{
PROPAGANDA IN A FUNCTION OF A SYSTEMIC INSTRUMENTALIZATION OF MEDIA FOR ULTRA-NATIONALIST PURPOSES
}

\begin{abstract}
Propaganda and its elements are an inseparable part of everyday life. In a digital age, when, in every second, a vast amount of information is exchanged, the possibilities and variations of propaganda techniques application are proportionally high. The majority of these propaganda messages that can be seen every time we turn on a device, or just go outside and look around are the messages of economic propaganda. Every time we hear a speech of a corporate or government official, we hear a carefully created and delivered message put together by public relations experts, which as well, by its genesis, belongs to propaganda. Still, the subject of this paper is propaganda, which is much more malicious in its origins and manifestations, and that is propaganda for ultranationalist purposes. In this paper, the authors first consider the etiological and historical aspects of propaganda focusing on those forms that had the most devastating effects. Propaganda predates mass media, but it is their conjunction that helped propaganda to reach a maximum capacity of its impact. Therefore, the authors analyze the correlation between propagandists, propaganda, and mass media.
\end{abstract}

Keywords: propaganda, communication, manipulation, mass media, nationalism

\footnotetext{
* PhD assistant professor, The Faculty of Economics and Engineering Management, The University of Business Academy, Novi Sad, e-mail: sasha.filipovic@gmail.com

${ }^{* *} \mathrm{PhD}$ assistant professor, The Faculty of Law for Commerce and Judiciary, The University Business of Academy, Novi Sad, e-mail: ivanas.milic@gmail.com
} 


\section{Introduction}

Propaganda, as a form of communication with a goal of promotion of specific ideas or plans of particular interest groups, is present in various forms since ancient times. Still, with the creation of mass communication media, as well as with certain large social events during the 20th century, on one side gave propaganda significance and power, but brought a loss of absolute neutrality which characterized it since it was created and defined. Today, with many examples to learn from, we generally receive propaganda as a negative phenomenon, closely tied with manipulation and engineering of consciousness and consent with citizens, whether it is in more benign forms, such as economic propaganda, or in its extremely harmful ways, often with tragic consequences, such as warmongering or ultra-nationalist propaganda. The term ,propaganda“ was derived from a modern Latin word ,propagare“, which roughly translates to ,to spread“ or „to propagate“. The term originated in the XVII century when the Roman Catholic Pope Gregory XV established the Congregatio de propaganda fide (Congregation for Propagating the Faith) to centralize the church's missionary activities under his control. This congregation, referred to informally as ,propaganda“, was a group of cardinals charged with directing church affairs in non-Catholic countries ${ }^{1}$. This organization was created as an answer to the Reformation movement, but the term „propaganda" soon grew out of church circles and entered the secular domain. Edward Bernays, a nephew of Sigmund Freud, is considered the pioneer of modern-sense propaganda, as well as a pioneer of public relations as an essential state, corporate and social activity. By leaning on his uncle's teachings, Bernays enveloped different aspects and ways to influence of consciousness of people in his opus, which is particularly visible in his books „Crystallizing Public Opinion“ from 1923, „Propaganda“ from 1928, and „The Engineering of Consent" from 1947, as well as in papers „Manipulating Public Opinion: The Why and the How", published in American Journal of Sociology in 1928 and „The Marketing of National Policies: A Study of War Propaganda“, published in Journal of Marketing in 1942.

We can conclude that propaganda has pejorative meaning in modern times since it is tied to the manipulation of public opinion with a goal of manufacturing consent, even in the academic sense. The historical moment when Bernays formulated his ideas coincided with the greatest atrocities humankind

\footnotetext{
${ }^{1}$ Diggs-Brown, B. (2011). Strategic Public Relations - Audience focused approach, Boston, Cengage Learning, p. 48.
} 
experienced in modern times, the greatest crimes and casualties and his teachings were misused for ultranationalist purposes to perfection. Here we shall make a distinction and say that in the case of Nazi Germany, the purpose indeed was an ultranationalist one. Still, in the case of the USSR, it wasn't, although we can find equally blatant and harmful examples of manipulating the populace through propaganda techniques. In both cases, propaganda was used for the promotion of ideology, but while the Nazi ideology was also an ultranationalist one, the Soviet one wasn't, since communism, by its nature, is an international movement and ideology. Nonetheless, if an ideology is nationalistic, that makes the combination particularly damaging and dangerous, although every form of propaganda is oriented on two sides - „for“ one and ,against" the other, where the others are most often victimized, so we can conclude that systemic propaganda is both the source of social conflicts and the fuel that makes the conflicts explode, and with additional development and diversification of mass media it becomes exponentially more dangerous.

\section{The theoretical and historical context of propaganda}

From a modern perspective, propaganda seems inseparable from media of mass communication, which have the ultimate potential for dissemination of information, as well as for engineering of consciousness and public opinion manipulation because of their efficacy, availability, and constant presence. Nonetheless, understanding of terms of oral, written, and electronic media allows panoramic, and in some measure, historical interpretation of the social role of communications. ${ }^{2}$ Every new medium that appeared had the previous one as its base, so we shall make a chronological summary of how propaganda was performed before the development of mass media. When we talk about mass media, therefore, we talk about modern electronic mass media and those whose base is in print. Mass communications is a broader matter, and to fully understand it we shall consider the communication role of the church, architecture, educational systems, painting, sculpture, coins, rites, and other as mass communication. ${ }^{3}$ Each of these forms of mass communication can be used for manipulation or manufacturing of opinion, which are consisting parts of propaganda since the beginnings of its use. The Roman Empire (lasting around 14 centuries, having started as the post-republican period of ancient Rome) was known for using propaganda, with many of the methods

\footnotetext{
${ }^{2}$ Lorimer, R. (1998). Masovne komunikacije [Mass Communication]. Beograd, Clio, p. 37.

${ }^{3}$ Ibid., p. 39.
} 
being used through art and even in the structural art and the architecture. Their methods range from visually pushing certain ideals, or within the stories that they passed on, often exaggerating certain figures or ideas to promote their motives. Propaganda mainly began within $30 \mathrm{BCE}$ and $330 \mathrm{CE}$, having been started by the emperors of that time, and it was used not only to push the personal status of the people and the rulers, but also to unify the empire and promote Pax Romana (Roman peace). Propaganda was used to inform the people of the daily happenings and anything important that must be to their knowledge, such as the success of the ruler and the army, among other things. Art (both through paintings and sculptures, many of the methods being used to promote a heroic image on a person or cause) was the main way of propaganda, as unlike other time periods, visual methods were one of the best ways to spread knowledge, as many things were documented through written word and many people being unable to read - they also did not have radios to widely broadcast information through speech. ${ }^{4}$ In addition to visual, propaganda was performed orally as well, through „,nuncii“ (Latin Singular „Nuncius“) who announced the news to gathered citizens on squares and other public spaces and, more often than not, the information to be reported were controlled by rulers, who controlled nuncii. In turbulent times, when rulers were often replaced, the nuncii were adapting their speeches to the current moment, which sometimes led to contradictory information being shared every next time when they spoke. In such ways, propaganda was performed even without media in the modern sense of that word, and the presence of propaganda techniques in manners of ruling and public communications existed even in first human civilizations.

Gutenberg's invention of the printing press marked the steppingstone for propaganda to reach a much more massive audience. The Reformation would not be possible without that invention, as it allowed Martin Luther to mass print the Bible in the German language, and it led the Catholic Church to establish a body that inspired the term ,propaganda“. The leaders of the French Revolution consciously employed all forms of art to mobilize public sentiment in favor of the new France and French nationalism. In the absence of mass media, artists were able to reach and influence a large number of the population who were not otherwise accessible to propaganda. ${ }^{5} \mathrm{We}$ had a

\footnotetext{
${ }^{4}$ Huzen, K. (2020). Propaganda Through the Ages, Christchurch, Middleton Grange College, pp. 2-3.

${ }^{5}$ Dowd, D. L. (1951). Art as National Propaganda in the French Revolution, Public Opinion Quarterly, 15 (3), pp. 532-546.
} 
similar situation during the American Revolution that took place a bit earlier. Mass printing was an excellent method, but it implied literacy of the recipients in cases of written messages, so visual message had greater importance, from illustrations, cartoons, and posters, to elite art. In America, where formal art had not advanced either technically or in popularity, artistic propaganda was primarily exhibited through political cartoons, though a few examples of propagandistic portraiture do exist. Here, tradesmen, not trained artists, produced art. Contrarily, while there was an equally productive culture of political cartooning and pornography in France, the greatest achievements in artistic propaganda here appear through historical and allegorical painting. ${ }^{6}$ Propaganda transformed in its modern form through war propaganda in the XX century. The pioneer of modern propaganda, Edward Bernays, when opening his office for public relations counseling, said, „I decided that if you can use propaganda for war, you can certainly use it for peace ${ }^{7 ”}$. Bernays then renamed propaganda to public relations, but the efficacy of the war propaganda, both in WWI and in Nazi Germany, has convinced him that people can be convinced of anything if the right things are being told to them in the right way and the right intervals.

Propaganda was the fundamental basis and tool of Nazims since the very beginning, initially through organizing the National Socialist Workers Party of Germany (Nationalsozialistische Deutsche Arbeiterpartei, NSDAP) and its predecessor, Workers' Party of Germany. In his book Mein Kampf, Adolf Hitler dedicated several chapters to propaganda, in contexts of war propagan$\mathrm{da}$ and the relation between propaganda and organization. „When I entered the German Labour Party I at once took charge of the propaganda, believing this branch to be far the most important for the time being. The first necessity was not so much to rack one's brains over problems connected with organization as to spread our ideas among as many people as possible. Propaganda should go well ahead of organization and gather together the human material for the latter to work up. ${ }^{8}$ " For purposes of information dissemination and obtaining media space, NSDAP acquired newspaper Volkischer Beobachter, which became an essential tool of propagating that party's ideas. After they won power in 1933, the party and its leader formed the Ministry for Public Enlightenment and Propaganda, headed by Joseph Goebbels. As the central

\footnotetext{
${ }^{6}$ Blair, M. (2008). Art as Propaganda in Revolutionary America and France - A Comparative Analysis, Mahurin Honors College Capstone Experience/Thesis Projects. Paper 102. (2020, Avgust, 30), Available at: https://digitalcommons.wku.edu/stu_hon_theses/102

${ }^{7}$ Diggs-Brown B., (2011). op. cit., p. 49.

${ }^{8}$ Hitler, A., (1925). Mein Kampf, Munich, Franz Eher Nachfolger, p. 620.
} 
office of Nazi propaganda, it comprehensively supervised and regulated the culture and mass media of Nazi Germany. ${ }^{9}$ In addition to the promotion of ideology, the cult of personality, total control over information, and equally important censorship, the Nazis recognized the potential of film in the advancement of propaganda, while practically making it an art form. Director Leni Riefenstahl was the most prominent film auteur of this ideology, and her documentary film „Triumph of the Will“ (Ger. Triumph des Willens), depicting the 6th Party Congress of NSDAP in Nuremberg, which gathered 700,000 people, contains the most iconic visual representations of Adolf Hitler, as well as Nazi iconography and choreography. While Leni Riefenstahl was subtle, particularly in her film „Olympia“, about the Olympic Games held in Berlin in 1936, there were much more crude propaganda films, particularly „The Eternal Jew" ("Der Ewige Jude") from 1940, made after the personal insistence of Joseph Goebbels, who additionally was personally involved in the production, which was a rarity for him. The Nazis gave special attention to rallies, where they used the charisma and oratorical skills of Adolf Hitler. A special department of the Ministry for Public Enlightenment and Propaganda worked on rallies, as they were an opportunity to communicate both visual and oral messages to a large mass of people. Both messages were carefully and elaborately created and delivered, through decorum, symbolism, and choreography for visual messages, and by exceptionally skilled oratory performances for verbal messages.

\section{Propaganda, media, and nationalism}

Considering the historical context of propaganda use, we can conclude that it most often followed revolutions and wars, meaning it had an ideological and/or nationalist base. In that sense, we shall add that one of the most efficient, successful, and comprehensive propaganda machines was run by the Soviet Union, created after a revolution that brought the Bolsheviks to power. When we talked about Nazi usage of film for propaganda purposes, we shall also mention Soviet film propaganda, and the film "The Battleship Potemkin" (Rusian: Бронено́сец „Потёмкин“) directed by Sergei Eisenstein (Russian: Сергей Эйзенштейн) from 1925, which in addition to being a propaganda film is a masterpiece of early cinema and significant artistic achievement. Soviet propaganda also used animated films, posters, and pamphlets, and the

\footnotetext{
${ }^{9}$ Manvell, R, Fraenkel, H. (2010). Doctor Goebbels - His Life and Death, New York, Skyhorse, pp. 140-141.
} 
fact that there is a permanent exhibition of Soviet revolutionary posters in Tate Modern ${ }^{10}$ in London speaks enough about its artistic quality. Naturally, all of these examples of modern propaganda imply the use of mass media. Nazis and Soviets used film and radio, controlled the press, and contemporary propaganda evolved with the development of each new medium of mass communication, particularly of television, as well as the Internet in the XXI century. Both television and the Internet created new ways of mass manipulation and manufacturing of consciousness and consent, reaching the people whom it was impossible to identify and reach by earlier means of mass communication.

Propaganda, and its consisting parts, would not be efficient if their action mechanism isn't a particular abuse of trust. Journalism, as one of the foundations of democracy, functions when journalists give information and analyses to the citizens, improve communication within society, and significantly allow self-government. Nonetheless, journalism, in its worst form, is one of the foundations of demagogy, despotism, and limited freedom. It quickly becomes a propaganda weapon for powerful interests ${ }^{11}$. In that way, the trust citizens have in their state, and their media becomes betrayed by manipulation mechanisms, which have several goals. Manipulation is never a goal in itself; it is always a means for achieving goals. One of the attributes of manipulation is that it can never be spontaneous, unplanned, and unintentional. ${ }^{12}$ As we could learn from historical examples, behind the manipulation as an inseparable part of propaganda is firstly a fundamental idea that is propagated, divided into as many pieces as it is necessary, for that idea to be spread fully and in the most desirable way. Other inseparable parts of propaganda are also achieved through media manipulation, such as the creation of public opinion and, in Bernays' words, "engineering of consent". The national role, although the most abstract, is the most staunch. Forcing of the national role is regularly done through the creation of national aces and national complexes created

\footnotetext{
${ }^{10}$ Tate Modern, Russian Revolutionary Posters, (2020, Septembar, 01), Available: https://www.tate. org.uk/whats-on/tate-modern/display/russian-revolutionary-posters

${ }^{11}$ Bjelajac, Ž., Filipović, A. (2018). Uticaj masovnih medija na degradaciju savremenog društva [Influence of Mass Media on Degradation of Contemporary Society]. in Bjelajac, Ž., Filipović, A. (eds.) Uticaj masovnih medija na degradaciju savremenog društva [Influence of Mass Media on Degradation of Contemporary Society]. special issue, Kultura polisa, pp. 9-21.

${ }^{12}$ Filipović, A. (2018). Manipulacija u medijima kao faktor degradacije savremenog društva [Media Manipulation as a Factor of Degradation of Contemporary Society]. in Bjelajac, Ž., Filipović, A. (eds.). Uticaj masovnih medija na degradaciju savremenog društva [Influence of Mass Media on Degradation of Contemporary Society]. special issue, Kultura polisa, pp. 45-60.
} 
in the model of the consciousness industry. ${ }^{13}$ That staunchness directly gives strength to nationalist propaganda, and nationalist propaganda strengthens nationalism and national homogeneity.

The first association on nationalism and its extreme forms, as an idea and a goal of propaganda, is Nazi Germany. Nonetheless, we live in the region and in time where we were direct witnesses of the devastating effects of ultranationalist propaganda during the Yugoslav Wars. Every Balkan country has its unfulfilled ultranationalist idea about a great state that would cover the ethnic distribution by its territory. The politicians, through skillful manipulation and lies, maintain the consciousness of their subjects about the size and power of their nation, about an injustice done to them, and about them, the politicians, who can rectify the historical injustice and prevent new ones from being done. ${ }^{14}$ Such an approach is harmful enough even in peacetime, as extreme forms of nationalism foster chauvinism and xenophobia, in addition to being based on myths and not the facts. With its massiveness and far-reach, with propaganda for nationalist purposes, we inevitably arrive at manipulation of the value system, through initial manipulation of patriotic feeling. Precisely that combination makes it possible for seemingly ordinary and peaceful people to commit unimaginable crimes in war conditions. Value system manipulation, in this case, revolves around the fact that the standard value system, which practically forbids people to do certain things to other human beings or living creatures, erodes in a way that the members of the other nation, who are targeted by both propaganda and ultranationalist tendencies of one country, are viewed as beings lesser than human, or sometimes lesser than other living beings, so it is not a crime nor something unethical if you do anything to them. If it weren't like that, we would not have heard for any Aushwitz, Jasenovac, Nanking, Sabra and Shatila, Srebrenica. In all those instances, propaganda allowed such massacres to happen as the public opinion of approval of such acts was created because it was in the interest of the nation. In some instances, the propaganda continues, so the genocide committed over ethnic Armenians by Turkey between 1914 and 1923 is officially called by that name by only 32 countries, while official Turkey still denies that the genocide happened, despite estimations of up to 1,5 million casualties and forced displacements. Otherwise, to further understand the systemic nature of that event, it is important to know that the crime was a continuation

\footnotetext{
${ }^{13}$ Nešković. R., (1981). Sveobuhvatnost industrije svesti [The totality of the industry of consciousness]. Kultura, (53), pp. 189-214.

${ }^{14}$ Filipović, A., op. cit.
} 
of Hamidian Massacres over ethnic Armenians committed between 1894 and 1896, with estimated casualties between 200,000 and 400,000 people.

In order for ultranationalist propaganda to be successful, it is clear that a firm control over mass media has to exist since they are the most critical disseminator of systemic propaganda. Such control, generally, can only be achieved by countries, and historical examples tell us that instigators and organizers of nationalist propaganda were always countries. It is nearly impossible for any interest group to act so harmfully on the majority population of a country without that country behind it all. Therefore it is crucial to develop democratic capacities, free media, and high social consciousness built on the humanist value system. Unfortunately, historical examples also tell us that all of that is not enough to prevent ultranationalism and its devastating consequences. Still, on the other side, although it does not prevent such tendencies from appearing, a society built on said principles has a capacity to lessen the probability of appearance of ultranationalist ideas and trends, as well as to resist if they appear. We already said that every new medium brings new possibilities for propaganda activities and reaches a greater number of people, so in the digital age, when the Internet is used by around $60 \%$ of the world population, we have nearly five billion people that can be homogenized and instrumentalized around, theoretically, any idea. If it were possible to homogenize all these people around something good for humankind, like environmental protection or helping those less fortunate, it would be a blessing, but a gathering of a large number of people around something constructive is far less inherent to human nature that fragmented gathering around something destructive. It is far easier to gather smaller but large enough numbers of people and unite them in hatred toward someone else, and that is another fact that explains how systemic ultranationalist propaganda quickly becomes dominant public discourse and views of the surrounding and the world.

\section{Discussion}

Nationalism and its extreme forms brought death and misfortune to hundreds of millions of people throughout human history. Only in WWII, there were between 70 million and 85 million casualties, out of which there were around 50 million civilians. The total number of victims amounted to $3 \%$ of the then-world population. In WWI, about 20 million people were killed, with a similar number of wounded, and the war-ravaged countries and societies faced a deadly pandemic of H1N1 influenza, the Spanish flu, which took another 100 million lives. In the First World War, just our country lost around a third of its 
population. While commenting on the influence of propaganda in WWI, Noam Chomsky wrote: „The First World War was the first time there was highly organized state propaganda. The British had a Ministry of Information, and they really needed it because they had to get the US into the war or else they were in bad trouble. The Ministry of Information was mainly geared to sending propaganda, including huge fabrications about "Hun" atrocities, and so on. They were targeting American intellectuals on the reasonable assumption that these are the people who are most gullible and most likely to believe propaganda. They are also the ones that disseminate it through their own system. So it was mostly geared to American intellectuals and it worked very well. The British Ministry of Information documents (a lot have been released) show their goal was, as they put it, to control the thought of the entire world, a minor goal, but mainly the US They didn't care much what people thought in India. This Ministry of Information was extremely successful in deluding hot shot American intellectuals into accepting British propaganda fabrications. They were very proud of that. Properly so, it saved their lives. They would have lost the first World War otherwise. In the US, there was a counterpart. Woodrow Wilson was elected in 1916 on an anti-war platform. The US was a very pacifist country. It has always been. People don't want to go fight foreign wars. The country was very much opposed to the first World War and Wilson was, in fact, elected on an anti-war position. "Peace without victory" was the slogan. But he was intending to go to war. So the question was, how do you get the pacifist population to become raving anti-German lunatics so they want to go kill all the Germans? That requires propaganda. So they set up the first and really only major state propaganda agency in US history. The Committee on Public Information it was called (nice Orwellian title), called also the Creel Commission. The guy who ran it was named Creel. The task of this commission was to propagandize the population into a jingoist hysteria. It worked incredibly well. Within a few months there was a raving war hysteria and the US was able to go to war. A lot of people were impressed by these achievements. One person impressed, and this had some implications for the future, was Hitler. If you read Mein Kampf, he concludes, with some justification, that Germany lost the first World War because it lost the propaganda battle. They could not begin to compete with British and American propaganda which absolutely overwhelmed them. He pledges that next time around they'll have their own propaganda system, which they did during the Second World War. ${ }^{15}$ " Naturally, war propaganda, which created public opinion

\footnotetext{
${ }^{15}$ Chomsky, N. (2003). Mediji, propaganda i sistem [Media, Propaganda and System]. Zagreb, Društvo za promicanje književnosti ka novim medijima, pp. 11-12.
} 
and consent, is not the sole culprit for such casualties, but many things that are happening in wars would not be possible without that engineering of consciousness and consent. Additionally, both world wars predate television, and particularly 24-hour news cycle and the Internet. The modern society, which we can call a "society of screens", is even more susceptible to propaganda, and the people, regardless of all historical lessons, technological progress, and increase of total human knowledge, are now possibly even more vulnerable to systematically instrumentalized media for any purpose, including the ultranationalist one.

The modern American propaganda machine generally is not based, nor it works for nationalist goals and purposes. The USA, as a nation created by immigrants from all over the world, is not immune to nationalism, which was visible many times through history, but as a hegemon after the WWII, and particularly as the sole superpower after the USSR was dissolved, has goals and interests that surpass fragmented nationalist interests. Simply put, they are so big and powerful that their interests, despite putting America first, are globalist and imperialist in their nature, and in the US, patriotism is far more present than nationalism, despite the two terms sometimes being overlapped. It is the same in Russia, with additional Soviet internationalist heritage. Playing the role of the world policeman does not necessarily imply nationalism, nor does the presence of interests of large powers in countries that are thousands of miles away, and with which they generally do not share values. Such interests are far broader and more elaborate than simple nationalism. Therefore, despite performing propaganda most efficiently and elaborately, it still differs from the kind of propaganda that is subject of this paper. Yet, although nationalism of the countries that control the propaganda is not a basis of it, the propaganda while working in the interest of these countries, often instigate ideological and nationalist ideas in target countries of the propaganda, which in turn encourages extremism and radicalization, whether as the desired product, or as a side product of the propaganda. The extremist propaganda is too widely available and distributed, particularly over the Internet, and has a direct influence on the radicalization and orientation of susceptible individuals. The toxic messages of extremists directly strike democracy, the rule of law, individual freedoms, respect and tolerance of different religions and beliefs, and values like freedom of speech or freedom of religion. ${ }^{16}$ In peacetime, a discourse generated by ultranationalist propaganda undermines the rule of law by spreading hate speech and instigating racial, religious, or national hatred,

\footnotetext{
${ }^{16}$ Bjelajac, Ž. (2017). Bezbednosna kultura - umeće življenja [Security Culture - Art of Living]. Novi Sad, Pravni fakultet za privredu i pravosuđe, p. 195.
} 
which is explicitly forbidden by legislative acts on several levels. In our legislation, Article 18 of the Constitution prescribes that regulations about human and minority rights are to be interpreted in favor of the advancement of values of a democratic society, in accordance to current international standards of human and minority rights, as well as in the practice of the international institutions that oversee their enforcement. ${ }^{17}$ In addition to the Constitution of the Republic of Serbia, several laws prohibit the hate speech, like the Law on the prohibition of discrimination, the Law on public information and media, the Law on electronic media, while the Criminal Code of the Republic of Serbia in Article 54a recognizes hate element of the crime as an aggravating circumstance when sentencing for a committed crime. ${ }^{18}$ Naturally, all of these provisions are related only to hate speech and crimes inspired by hate, and the totality of propaganda contains numerous additional challenges, both for the legal system and the society as a whole.

\section{Conclusions}

Regardless of its harmfulness, which we modestly illustrated in this paper, propaganda, including the ultranationalist one, cannot be eradicated. One part of the reasons for that is in human nature, and human tendency to present personal interests as collective ones to achieve them easier, and another part of reasons is in the application of propaganda techniques for purposes that per se are not harmful to society or citizens. Naturally, as long as we use the term "propaganda," it will have a negative connotation, and it will be perceived as its most harmful form, similar to the use of the word "manipulation". We will mention Edward Bernays once more and remind that himself, very aware of the negative association that the word "propaganda" brings practically renamed the same thing to "public relations". Naturally, since that time that human activity dispersed around the world and was perfected, so today there is almost no media content that is not created with PR principles in mind or does not contain some elements of propaganda, even in the sports telecasts, where we can regularly see elements of economic propaganda. And while the constitution prohibits hate speech, it guarantees the freedom of speech and expression at the same time. Media laws guarantee freedom of information but simultaneously

\footnotetext{
${ }^{17}$ Stojković, M., Pokuševski, D. (2018). Anonimna mržnja - mehanizmi zaštite od govora mržnje na internetu, Beograd [Anonymous hate - hate speech protection mechanisms]. Beograd, Beogradski centar za ljudska prava, p. 17.

${ }^{18}$ Krivični zakonik Republike Srbije, [Criminal Code of the Republic of Serbia], Službeni glasnik $R S$, br. 85/05 - ispr., 107/05 - ispr., 72/09, 111/09, 121/12, 104/13, 108/14, 94/16 i 35/19.
} 
prescribe prohibition of distribution of certain information. On the other side, public relations, and particularly propaganda, understood more widely that the PR is well-funded and well-staffed, and these experts constantly find new forms of communicating the information. If the systemic instrumentalization of the media for ultranationalist purposes occurs, then things become more complex, as they are already more complex due to the level of technological progress, human culture, and everyday life. Therefore, a coherent strategy for combatting radicalism and extremism demands the development of institutions necessary for the improvement of human safety and prevention of these dangerous occurrences in the society ${ }^{19}$. Additionally, it is essential to continuously work on the improvement of the culture of tolerance and development and sustainability of a shared value system based on the humanist values. In the opposite, we, as a global society, risk the repeating of some of the greatest horrors the humankind has seen in the future, and we risk the appearance of new atrocities, some of which, like religious terrorist organizations, we have already seen in action, and whose activities changed the way we live.

\section{Filipović Aleksandar}

Dr, Docent, Fakultet za ekonomiju i inženjerski menadžment, Univerzitet Privredna akademija Novi Sad

\section{Spaić Ivana}

Dr, Docent, Pravni fakultet za privredu i pravosuđe, Univerzitet Privredna akademija Novi Sad

\section{PROPAGANDA U FUNKCIJI SISTEMSKE INSTRUMENTALIZACIJE MEDIJA U ULTRANACIONALISTIČKE SVRHE}

REZIME: Propaganda, i njeni elementi, neodvojivi su deo svakodnevnog života. U digitalno doba, kada se svake sekunde razmeni ogromna količina informacija, mogućnosti i varijacije primene propagandnih tehnika su proporcionalno velike. Najveći deo tih propagandnih poruka koje možemo da

${ }^{19}$ Bjelajac, Ž., op. cit. pp. $240-241$. 
vidimo svaki put kada uključimo neki uređaj, ili izađemo na ulicu i pogledamo okolo, spadaju u ekonomsku propagandu. Svaki put kada čujemo obraćanje nekog korporativnog ili državnog zvaničnika čujemo pažljivo kreiranu i isporučenu poruku koju su sastavili stručnjaci za odnose sa javnošću, koji takođe, po svojoj genezi, spadaju u propagandu. Ipak, predmet ovog rata je propaganda koja je značajno malicioznija i u svom nastajanju i u svojim pojavnim oblicima, a to je propaganda u ultranacionalističke svrhe. U ovom radu autori najpre razmatraju etiološke i istorijske aspekte propagande, sa fokusom na one njene forme koje su donele najrazornije delovanje. Propaganda predatira medije masovne komunikacije, ali je upravo pomoću njih dostigla maksimalne kapacitete svog dejstva, pa stoga autori razmatraju korelativnost između propagandista, propagande i medija masovne komunikacije.

Ključne reči: propaganda, komunikacija, manipulacija, masovni mediji, nacionalizam

\section{References}

1. Bjelajac, Ž., (2017). Bezbednosna kultura - umeće življenja [Security Culture - Art of Living]. Novi Sad, Pravni fakultet za privredu i pravosuđe

2. Bjelajac, Ž., Filipović, A., (2018). Uticaj masovnih medija na degradaciju savremenog društva [Influence of Mass Media on Degradation of Contemporary Society]. in Bjelajac, Ž., Filipović, A. (eds.) Uticaj masovnih medija na degradaciju savremenog društva [Influence of Mass Media on Degradation of Contemporary Society]. special issue, Kultura polisa, pp. $9-21$

3. Blair, M., (2008). Art as Propaganda in Revolutionary America and France: A Comparative Analysis Mahurin Honors College Capstone Experience/ Thesis Projects. Paper 102. Available at: https://digitalcommons.wku. edu/stu_hon_theses/102

4. Chomsky, N. (2003). Mediji, propaganda i sistem [Media, Propaganda and System]. Zagreb, Društvo za promicanje književnosti ka novim medijima

5. Diggs-Brown B. (2011). Strategic Public Relations - Audience focused approach, Boston, Cengage Learning

6. Dowd, D. L. (1951). Art as National Propaganda in the French Revolution, Public Opinion Quarterly, 15 (3), pp. 532-546 
7. Filipović, A. (2018). Manipulacija u medijima kao faktor degradacije savremenog društva [Media Manipulation as a Factor of Degradation of Contemporary Society]. in Bjelajac, Ž., Filipović, A. (eds.) Uticaj masovnih medija na degradaciju savremenog društva [Influence of Mass Media on Degradation of Contemporary Society]. special issue, Kultura polisa, pp. $45-60$

8. Hitler, A., (1925). Mein Kampf, Munich, Franz Eher Nachfolger

9. Huzen, K., (2020). Propaganda Through the Ages, Christchurch, Middleton Grange College

10. Krivični zakonik [Criminal Code of the Republic of Serbia], Službeni glasnik $R S$, br. 85/05 - ispr., 107/05 - ispr., 72/09, 111/09, 121/12, 104/13, 108/14, 94/16 i 35/19

11. Lorimer R. (1998). Masovne komunikacije [Mass Communication]. Beograd, Clio

12. Manvell, R; Fraenkel, H. (2010). Doctor Goebbels: His Life and Death, New York, Skyhorse

13. Nešković. R., (1981). Sveobuhvatnost industrije svesti [The totality of the industry of consciousness], Kultura, (53), pp. 189-214

14. Stojković, M., Pokuševski, D. (2018). Anonimna mržnja - mehanizmi zaštite od govora mržnje na internetu [Anonymous hate - hate speech protection mechanisms], Beograd, Beogradski centar za ljudska prava

15. Tate Modern, Russian Revolutionary Posters, Available at: https://www. tate.org.uk/whats-on/tate-modern/display/russian-revolutionary-posters 